\title{
EKSTRAK ETANOL KACANG TANAH MENURUNKAN MALONDIALDEHID PLASMA DAN MENINGKATKAN FUNGSI MOTORIK TIKUS MODEL STROKE ISKEMIK
}

(EFFECT OF ETHANOL PEANUT EXTRACT (Arachis hypogaea) ON PLASMA

\section{MALONDIALDEHYDE AND MOTORIC FUNCTION IN ISCHEMIC RAT STROKE MODEL)}

\author{
$\underline{\text { Henny Juliastuti }^{*}}$, Fairuz Rifani ${ }^{1}$, Lia Siti Halimah ${ }^{2}$ \\ ${ }^{1}$ Laboratorium Biokimia Biomolekular Fakultas Kedokteran Universitas Jenderal Achmad \\ Yani Cimahi Indonesia \\ ${ }^{2}$ Laboratorium Mikrobiologi Fakultas Kedokteran Universitas Jenderal Achmad Yani Cimahi \\ Indonesia \\ E-mail korespondensi: juliastuti.henny@gmail.com
}

\begin{abstract}
ABSTRAK
Prevalensi stroke di Indonesia berdasarkan Riset Kesehatan Dasar (Riskesdas) 2013 sebesar 7 per 1000 penduduk dengan stroke iskemik sebagai etiologi terbesar yaitu 87\% kasus. Stroke iskemik terjadi akibat penurunan aliran darah otak sehingga menimbulkan cedera pada daerah yang dialirinya. Kacang tanah (Arachis hypogaea) memiliki kandungan resveratrol yang memiliki efek terapeutik pada penyakit neurodegeneratif, uptake glutamat, dan menurunkan produksi radikal bebas sehingga berperan dalam plastisitas neuron. Penelitian ini merupakan penelitian eksperimental, dan bertujuan untuk mengetahui efek ekstrak etanol kacang tanah terhadap malondialdehid (MDA) plasma dan fungsi motorik tikus jantan galur Wistar model stroke iskemik. Subjek penelitian berjumlah 23 ekor tikus, dibagi menjadi empat kelompok yaitu kelompok kontrol negatif (KKN) yang tidak diberi perlakuan, kelompok kontrol positif (KKP) yang diinduksi stroke, kelompok perlakuan 1 (KP1) yang diinduksi stroke, dan diberi ekstrak etanol kacang tanah dosis $131 \mathrm{mg} / 250 \mathrm{gBB}$ serta kelompok perlakuan 2 (KP2) yang diinduksi stroke, dan diberi ekstrak etanol kacang tanah dosis $262 \mathrm{mg} / 250 \mathrm{gBB}$. Penelitian dilakukan dengan cara menginduksi tikus dengan pengikatan arteri karotis komunis kiri selama 45 menit kemudian pemberian ekstrak secara peroral pada KP1 dan KP2 selama 2 minggu, selanjutnya
\end{abstract}


Juliastuti, H : Ekstrak Etanol Kacang Tanah...

dilakukan pemeriksaan fungsi motorik, dan MDA plasma. Berdasarkan uji one-way ANOVA tidak terdapat perbedaan yang signifikan antara hasil MDA pada KKN dan KP2 (p=0,065). Tidak terdapat perbedaan yang signifikan antara skor ladder rung walking task pada KKN, dan KP2 (p=0,409). Ekstrak etanol kacang tanah dosis $262 \mathrm{mg} / 250 \mathrm{gBB}$ merupakan dosis efektif dalam menurunkan kadar MDA, dan meningkatkan fungsi motorik pada tikus model stroke iskemik.

Kata kunci: kacang tanah; malondialdehid; stroke iskemik

\section{ABSTRACT}

Prevalence of stroke in Indonesia is $0.7 \%$ according to Riskesdas 2013 as ischemic stroke is the etiology of $87 \%$ cases. Ischemic stroke occurs as a result of blood flow reduction to cause brain injury. The medication given on ischemic stroke are not able to repair neuronal damage. Peanuts (Arachis hypogaea) is containing resveratrol which has a therapeutic effect on neurodegenerative diseases, glutamate uptake, and reducing free radicals. Resveratrol plays a role on neuron plasticity. This study is an experimental research and aimed to determine the effect of ethanol peanut extract on plasma MDA and motoric function of rodent ischemia stroke model. Total subject on this study is 23 male Wistar strained rodent divided into 4 groups which are negative control group $(K K N)$, positive control group $(K K P)$, treatment group $1(K P 1)$ with $131 \mathrm{mg} / 250 \mathrm{~g}$ weight dosage of ethanol peanut extract given, and treatment group 2 (KP2) with $262 \mathrm{mg} / 250 \mathrm{~g}$ weight dosage of ethanol peanut extract given. Stroke induction is done by occluding left common carotid artery for 45 minutes, the extract is given peroral on KPI and KP2 for 2 weeks, motor function and plasma MDA is measured on the next day. According to one-way ANOVA test, there were no significant difference in MDA between KKN and KP2 $(p=0,065)$ and also there were no significant difference in motor function between KKN and KP2 $(p=0,409)$. The $262 \mathrm{mg} / 250 \mathrm{~g}$ weight dosage of ethanol peanut extract is an effective dose to reduce MDA and improve motor function in rodent ischemic stroke model.

Keywords: ischemic stroke; malondialdehyde; peanut

\section{PENDAHULUAN}

Stroke adalah penyakit pada sistem saraf pusat yang ditandai dengan adanya gangguan fungsi saraf fokal dan/atau global yang muncul mendadak akibat adanya gangguan pembuluh darah otak. ${ }^{1-3}$ Hilangnya pasokan darah ke otak menyebabkan kerusakan sel neuron sehingga menimbulkan manifestasi klinis seperti parese, dan hipestesi sesuai lokasi 
Juliastuti, H : Ekstrak Etanol Kacang Tanah...

otak yang kehilangan pasokan darah., ${ }^{1,2}$ Prevalensi stroke di Indonesia berdasarkan data Riskesdas tahun 2013 adalah sebesar 7 per 1000 penduduk dengan penyebab stroke iskemik lebih banyak terjadi daripada stroke perdarahan yaitu sebanyak 87\%.4-6 Kematian neuron diperantarai salah satunya dengan adanya stres oksidatif atau nitrosatif sehingga membentuk radikal bebas. Radikal bebas ini akan memutus rantai asam lemak neuron, dan menjadi senyawa toksik MDA. ${ }^{7-}$ ${ }^{9}$ Arteri serebri anterior yang memperdarahi korteks parasagital akan memiliki manifestasi klinis berupa paralisis, dan hipertesi kontralateral bila mengalami stroke. ${ }^{2,10}$

Obat yang diberikan pada pasien stroke saat ini bertujuan untuk meminimalisasi cedera, dan komplikasi yang dapat terjadi tanpa memperbaiki kerusakan neuron yang telah terjadi. ${ }^{11-13}$ Resveratrol adalah senyawa stilbenoid yang secara alami terdapat pada anggur, kacang tanah, nanas. ${ }^{14,15}$ Beberapa hasil penelitian menyebutkan bahwa resveratrol memiliki efek terapeutik pada penyakit neurodegeneratif dengan menginduksi pengeluaran neurotrophic factor yang berperan dalam plastisitas neuron sehingga mampu bertahan dan beradaptasi terhadap kerusakan yang telah terjadi. ${ }^{16-18}$ Resveratrol pada kacang tanah (Arachis hypogaea) terdapat pada akar sampai daunnya dengan kadar $0,022 \mu \mathrm{g} / \mathrm{g}$ sampai 1,792 $\mu \mathrm{g} / \mathrm{g} .{ }^{20}$ Hasil penelitian Candelario-jalil tahun 2007 yang melibatkan mikroglia tikus melaporkan bahwa resveratrol mampu melintasi sawar darahotak, dan dapat menurunkan kerusakan otak yang disebabkan cedera iskemik. ${ }^{21,22}$

Penelitian tentang stroke iskemik telah banyak berhasil dilakukan pada hewan coba tikus dengan membuat model stroke iskemik, salah satunya pada penelitian Lukito (2016) dengan ligasi pada arteri karotis komunis tikus Wistar selama 45 menit, dan didapatkan penurunan fungsi motorik yang signifikan setelah dilakukan reperfusi. $^{23,24}$ Distribusi kacang tanah di Indonesia terluas berada di Jawa Barat. ${ }^{25}$ Penelitian yang dilakukan oleh Desun (2011) membuktikan bahwa ekstrak kacang tanah dengan dosis $15 \mathrm{mg} / 20 \mathrm{gBB}$ mencit dan $30 \mathrm{mg} / 20 \mathrm{gBB}$ mencit mampu menurunkan jumlah kerusakan hepatosit karena memiliki kandungan polifenol. ${ }^{26}$ Kandungan polifenol dalam kacang tanah mampu melindungi hepar terhadap radikal bebas namun belum ada penelitian yang menunjukkan bahwa ekstrak etanol kacang tanah mampu menurunkan produksi radikal bebas dilihat dengan parameter MDA pasca stroke, dan memperbaiki fungsi motorik dengan parameter skor ladder rung walking task. $^{27}$ Penelitian ini bertujuan untuk mengetahui efek ekstrak etanol kacang tanah terhadap kadar MDA plasma dan fungsi 
Juliastuti, H : Ekstrak Etanol Kacang Tanah...

motorik tikus jantan galur Wistar model stroke iskemik.

\section{BAHAN DAN METODE}

\section{Subjek Penelitian}

Pada penelitian digunakan 24 ekor tikus putih jantan galur Wistar, berusia 8-10 minggu, mempunyai berat badan rerata 250 gram yang memiliki gerak aktif, dan nafsu makan baik.

\section{Tempat dan Waktu Penelitian}

Penelitian dilakukan di Laboratorium Percobaan Hewan, Laboratorium Biokimia, dan Biomolekular Fakultas Kedokteran Universitas Jenderal Achmad Yani (FK Unjani) sedangkan pembuatan ekstrak dilakukan di Gedung Riset, dan Inovasi Institut Teknologi Bandung (ITB). Penelitian dilaksanakan mulai bulan Oktober 2018 sampai dengan bulan Februari 2019.

\section{Alat dan Bahan Pemeriksaan}

Alat penelitian yang digunakan pada induksi stroke adalah disposable syringe, minor set steril, benang prolene 6.0 , doek bolong, meja operasi, kapas, pencukur bulu, dan kassa steril. Alat penelitian yang digunakan pada pemeriksaan MDA adalah tabung centrifuge, alat centrifuge, tabung eppendorf, tabung reaksi, mikropipet, kuvet semi mikro, kelereng, dan spektrofotometer. Alat penelitian yang digunakan pada pemeriksaan fungsi motorik adalah ladder rung walking apparatus, kamera DSLR, laptop, dan alat tulis.

Bahan penelitian yang digunakan pada induksi stroke adalah $\mathrm{NaCl}$ 0,9\%, ketamine, xylazine, alkohol. Bahan penelitian yang digunakan pada pemeriksaan MDA adalah larutan standar, larutan BHT, larutan SDS, larutan EDTA, larutan asam asetat, dan larutan TBA 0,8\%.

\section{Aklimatisasi}

Dua puluh empat ekor tikus didapat dari PT Biofarma dengan menggunakan empat kandang berisi enam tikus tiap kandang. Aklimatisasi tikus selama tujuh hari dilakukan dengan kelompok tikus yang sama setiap kandangnya untuk mencegah stres dalam adaptasi dengan kelompok baru.

\section{Ekstrak Etanol Kacang Tanah}

Bagian tanaman kacang tanah yang digunakan pada penelitian adalah biji kacang tanah beserta kulit arinya. Kacang tanah dicuci sampai bersih kemudian dikeringkan di udara terbuka sampai cukup kering selanjutnya pengeringan dilanjutkan dalam oven pada suhu $40-60^{\circ} \mathrm{C}$ lalu dibuat serbuk. Serbuk kering biji kacang tanah diekstraksi secara maserasi menggunakan pelarut etanol $96 \%$ sampai terendam seluruhnya selama 24 jam pada suhu ruangan kemudian disaring dengan kertas penyaring. Ekstrak hasil maserasi ditampung dan diuapkan agar pelarut terpisah. 
Juliastuti, H : Ekstrak Etanol Kacang Tanah...

Penguapan dilakukan dengan rotary evaporator pada suhu $45-50^{\circ} \mathrm{C}$ sampai pelarut habis menguap sehingga didapatkan ekstrak kacang tanah yang siap digunakan untuk penelitian.

\section{Induksi Stroke}

Stroke iskemik pada tikus dibuat oklusi model transien lokal dengan cara ligasi arteri karotis komunis kiri. Dilakukan anestesi pada tikus dengan ketamine, dan xylazine dosis $40 \mathrm{mg} / \mathrm{kgBB}$, dan 10 $\mathrm{mg} / \mathrm{kgBB}$ secara intraperitoneal, kemudian dilakukan fiksasi di atas meja bedah steril dengan posisi supinasi. Bulu di bagian leher tikus dicukur, lalu dilakukan tindakan aseptik antiseptik. Tikus selanjutnya dilakukan insisi pada garis tengah leher secara vertikal sepanjang 2-3 cm. Setelah dilakukan identifikasi arteri karotis komunis kiri selanjutnya dilakukan ligasi dengan benang prolene 6.0 selama 45 menit.

\section{Pasca Induksi Stroke}

Ikatan prolene pada arteri karotis komunis dilepas setelah 45 menit. Luka insisi dijahit dengan benang catgut, dan diolesi analgesik topikal lidokain krim, dan antibiotik krim, luka jahitan ditutup dengan kassa steril. Monitor perilaku tikus setelah induksi stroke dilakukan dalam 48 jam pertama dengan minimal handling.

\section{Pengukuran Fungsi Motorik}

Pengukuran fungsi motorik tikus model stroke iskemik menggunakan foot fault scoring system. Metz \& Whisaw pada ladder rung walking task. Setelah 14 hari tikus diberi perlakuan pemberian ekstrak maka keesokan harinya akan diperiksa fungsi motoriknya. Tikus akan berjalan pada alat ladder rung walking task yang berjarak satu meter, bersamaan dengan itu diletakkan kamera dari arah samping untuk merekam pergerakan tikus. Kamera diatur pada kecepatan shutter 500-2000 detik, dan akan dianalisis per frame pada $30 \mathrm{f} / \mathrm{detik}$.

\section{Pemeriksaan Kadar MDA Plasma}

Darah sampel yang diambil dari vena retroorbita disentrifugasi dengan kecepatan 3000 rpm selama 10 menit, dan diambil plasmanya masing-masing $400 \mu \mathrm{l}$ yang dimasukkan ke dalam tabung reaksi yang sudah diberi label sesuai kelompoknya. Setelah plasma dimasukkan, ditambahkan akuades sebanyak $300 \mu$, larutan SDS 200 $\mu \mathrm{l}$, dan untuk mencegah oksidasi lipid selama pengujian ditambahkan BHT $50 \mu$, dan larutan EDTA $50 \mu 1$, larutan asam asetat sebanyak 1,5 ml, dan TBA sebanyak 1,5 ml. campuran dipanaskan selama 30 menit dalam air mendidih $\left(100^{\circ} \mathrm{C}\right)$, dan masingmasing tabung ditutup dengan kelereng. Setelah dipanaskan dengan air mendidih, sampel direndam dalam bak berisi air es. Sampel kemudian disentrifus dengan kecepatan 3000 rpm selama 10 menit. 
Juliastuti, H : Ekstrak Etanol Kacang Tanah...

Supernatan dari tiap tabung diambil kemudian dibaca dengan alat spektrofotometer pada panjang gelombang $532 \mathrm{~nm}$.

\section{Analisis Data}

Skala pengukuran data berupa numerik sehingga perlu dilakukan analisis deskriptif data numerik dengan SPSS untuk mengetahui rerata nilai kadar MDA, dan fungsi motorik pada tiap kelompok. Analisis data selanjutnya adalah untuk mengetahui kelompok mana yang memberi pengaruh secara signifikan terhadap kadar MDA, dan fungsi motorik dari tiap kelompok, Data terdistribusi normal, dan homogen sehingga dilakukan uji beda untuk lebih dari dua kelompok menggunakan uji one way Anova kemudian dilakukan uji Post Hoc Tukey.

\section{Aspek Etika Penelitian}

Penelitian ini telah mendapat surat izin dari Komisi Etik Penelitian Kesehatan

Tabel 1 Pengaruh pemberian ekstrak etanol kacang tanah terhadap kadar MDA keempat kelompok perlakuan

\begin{tabular}{cccccc}
\hline Variabel & $\begin{array}{c}\text { Jumlah } \\
\text { kuadrat } \\
\text { dalam }\end{array}$ & df & $\begin{array}{c}\text { Rerata } \\
\text { kuadrat }\end{array}$ & F & Nilai p \\
\hline Antar kelompok & 0,022 & 3 & 0,007 & 25,669 & $0,000^{*}$ \\
$\begin{array}{c}\text { Dalam kelompok } \\
\text { Total }\end{array}$ & 0,005 & 19 & 0,000 & & \\
\hline 0,028 & 22 & & & \\
\hline
\end{tabular}

Keterangan: Hasil Uji One way Anova: nilai *p<0,05 (terdapat perbedaan bermakna) 
Juliastuti, H : Ekstrak Etanol Kacang Tanah...

Pengaruh pemberian ekstrak etanol kacang tanah terhadap kadar MDA keempat kelompok perlakuan pada Tabel 1 menunjukkan terdapat perbedaan kadar MDA yang signifikan antar kelompok dengan hasil nilai signifikasi $\mathrm{p}=0,000$. Hal ini menunjukkan bahwa terdapat efek ekstrak etanol kacang tanah dalam menurunkan kadar MDA akibat stres oksidatif yang ditimbulkan keadaan iskemik otak. Selanjutnya dilakukan uji post hoc Tukey untuk mengetahui pada kelompok yang menunjukkan adanya perbedaan tersebut atau kelompok yang memberikan pengaruh signifikan terhadap kadar MDA tikus jantan galur Wistar.

Tabel 2 Perbedaan rerata kadar MDA antar kelompok perlakuan

\begin{tabular}{ccl}
\hline Kelompok & Pembanding & Nilai p \\
\hline \multirow{2}{*}{ KKN } & KKP & $0,000^{*}$ \\
& KP1 & $0,000^{*}$ \\
\multirow{2}{*}{ KKP } & KP2 & 0,065 \\
& KP1 & $0,016^{*}$ \\
& KP2 & $0,000^{*}$ \\
\hline
\end{tabular}

Keterangan: Hasil uji post hoc: nilai $* \mathrm{p}<0,05$ (terdapat perbedaan bermakna);KKN: Kelompok Kontrol Negatif; KKP: Kelompok Kontrol Positif; KP: Kelompok Perlakuan

Berdasarkan hasil pengujian post hoc pada Tabel 2 terlihat bahwa semua kelompok mempunyai perbedaan terhadap kelompok pembanding antara kelompok perlakuan 1 (KP1) dan kelompok perlakuan 2 (KP2). Hasil ini dilihat dari nilai $\mathrm{p}<0,05$ yang berarti terdapat perbedaan yang signifikan antara kelompok kontrol positif dengan kelompok perlakuan. Dari hasil uji banding ganda didapatkan bahwa tidak terdapat perbedaan yang signifikan antara hasil MDA pada kelompok kontrol negatif (KKN) dan kelompok perlakuan 2 (KP2) yang berarti bahwa pemberian ekstrak etanol kacang tanah dosis $262 \mathrm{mg} / 250 \mathrm{gBB}$ tikus menghasilkan penurunan kadar MDA terhadap tikus yang diinduksi stroke iskemik sampai mendekati kadar normal.

Induksi stroke pada tikus dengan melakukan oklusi pada arteri karotis komunis kiri menyebabkan pasokan aliran darah ke otak yang diperdarahi oleh sistem arteri tersebut, sehingga jumlah oksigen, dan glukosa ke jaringan otak menjadi menurun bahkan berhenti. Akibat adanya penghentian suplai oksigen, dan glukosa menyebabkan pembentukan ATP menjadi berkurang karena fosforilasi oksidatif tidak terjadi. Kadar ATP yang rendah menyebabkan kegagalan fungsi gerbang ion $\mathrm{Na}^{+} / \mathrm{K}^{+} /$ATPase sehingga terjadi kegagalan pompa $\mathrm{Na}^{+} / \mathrm{Ca}^{2+}$ dan $\mathrm{Ca}^{2+}$ akan terjebak di 
Juliastuti, H : Ekstrak Etanol Kacang Tanah...

dalam sel neuron sehingga menyebabkan pelepasan glutamat yang merupakan neurotransmiter eksitatorik sehingga terjadi eksitotoksisitas. Kadar $\mathrm{Ca}^{2+}$ intraseluler yang tinggi juga menginduksi terjadinya stres oksidatif/nitrosatif sehingga akan menyebabkan kerusakan mitokondria dan organel lain akibat peningkatan pembentukan radikal bebas. Radikal bebas menyebabkan auto-oksidasi lipid sehingga menyebabkan rantai asam lemak pada membran neuron menjadi terputus dan menjadi senyawa toksik MDA. ${ }^{3,9}$

Meskipun stres oksidatif yang menghasilkan MDA secara lokal terjadi di otak namun MDA mampu masuk ke dalam pembuluh darah. akan beredar secara sistemik dalam pembuluh darah hingga mampu mencapai vena retroorbita. Kadar MDA yang diperiksa diambil dari sampel darah vena retroorbita sehingga mampu menggambarkan kadar MDA dalam otak.

Ekstrak etanol kacang tanah diberikan secara peroral, dan akan diabsorpsi melalui saluran cerna hingga akhirnya mencapai pembuluh darah dan beredar secara sistemik hingga mencapai aliran darah otak. Resveratrol dalam kacang tanah mampu melintasi sawar darah otak atau blood-brain barrier (BBB). Mekanisme kerja resveratrol terhadap penurunan kadar MDA adalah dengan menurunkan produksi NO ketika terjadi peningkatan nNOS atau ROS. Penurunan kadar NO selanjutnya akan mencegah stres oksidatif sehingga mampu menurunkan peroksidasi lipid, oksidasi protein, dan fragmentasi DNA. Sifat antioksidan resveratrol tersebut menyebabkan kadar MDA menjadi menurun. ${ }^{9}$

\section{Pengaruh Pemberian Ekstrak Etanol} Kacang Tanah terhadap Fungsi Motorik

\section{Tikus Model Stroke Iskemik}

Data rerata skor ladder rung walking task didapatkan pada kelompok kontrol negatif (KKN) sebesar 135,60 \pm 1,817; kelompok kontrol positif (KKP) sebesar $122,33 \pm 3,141$; kelompok perlakuan 1 (KP1) sebesar 128,00 \pm 3,899; dan kelompok perlakuan 2 (KP2) sebesar 131,50 $\pm 6,442$. Selanjutnya dilakukan uji One way Anova untuk mengetahui perbedaan antara semua kelompok. Hasil uji One way Anova untuk kadar MDA dapat dilihat pada Tabel 3. 
Juliastuti, H : Ekstrak Etanol Kacang Tanah...

Tabel 3 Pengaruh pemberian ekstrak etanol kacang tanah terhadap skor ladder rung walking task keempat kelompok perlakuan

\begin{tabular}{lccccc}
\hline \multicolumn{1}{c}{ Variabel } & Jumlah kuadrat dalam & df & Rerata kuadrat & F & Nilai p \\
\hline Antar kelompok & 527,793 & 3 & 175,931 & 9,660 & $0,000^{*}$ \\
Dalam kelompok & 346,033 & 19 & 18,212 & & \\
Total & 873,826 & 22 & & & \\
\hline
\end{tabular}

Keterangan: Hasil Uji One way Anova: nilai p<0,05 (terdapat perbedaan bermakna)

Pengaruh pemberian ekstrak etanol kacang tanah terhadap skor ladder rung walking task pada Tabel 3 menunjukkan perbedaan signifikan dengan nilai signifikansi nilai $\mathrm{p}=0,000$ maka hipotesis $\mathrm{Ho}$ ditolak. Hal ini menunjukkan terdapat pengaruh pemberian ekstrak etanol kacang tanah terhadap skor ladder rung walking task di antara keempat kelompok tersebut. Selanjutnya dilakukan uji post hoc Tukey untuk mengetahui pada kelompok mana yang menunjukkan adanya perbedaan tersebut atau kelompok mana yang memberikan pengaruh signifikan terhadap skor ladder rung walking task tikus jantan galur wistar yang disajikan pada Tabel 4.

Tabel 4 Perbedaan rerata skor ladder rung walking task antar kelompok perlakuan

\begin{tabular}{ccc}
\hline Kelompok & Pembanding & Nilai p \\
\hline \multirow{2}{*}{ KKN } & KKP & $0,001^{*}$ \\
& KP1 & $0,038^{*}$ \\
KKP & KP2 & 0,409 \\
& KP1 & 0,113 \\
KP2 & $0,007^{*}$ \\
\hline
\end{tabular}

Keterangan: Hasil uji banding ganda: nilai $* \mathrm{p}<0,05$ (terdapat perbedaan bermakna); KKN: Kelompok Kontrol Negatif; KKP: Kelompok Kontrol Positif; KP: Kelompok Perlakuan

Berdasarkan hasil pengujian post hoc Tukey pada Tabel 4 terlihat bahwa semua kelompok mempunyai pengaruh antara kelompok perlakuan 1 (KP1), kelompok perlakuan 2 (KP2) dengan kelompok kontrol negatif (KKN), dan kelompok kontrol positif (KKP). Hasil ini dilihat dari nilai $\mathrm{p}<0,005$. Berdasarkan hasil uji banding ganda didapatkan bahwa tidak terdapat perbedaan yang signifikan antara skor ladder rung walking task pada $\mathrm{KKN}$ dan KP2 yang berarti bahwa pemberian ekstrak etanol kacang tanah dosis $262 \mathrm{mg} / 250 \mathrm{gBB}$ tikus selama 14 hari memberikan pengaruh meningkatkan fungsi motorik dilihat dari skor ladder rung walking task yang meningkat mendekati keadaan normal. 
Juliastuti, H : Ekstrak Etanol Kacang Tanah...

Ekstrak etanol kacang tanah mengandung resveratrol yang mampu melintasi sawar darah otak. Resveratrol berperan terhadap pengeluaran neurotrophic factor ketika terjadi kerusakan neuron. Resveratrol juga berperan terhadap plastisitas neuron dengan meningkatkan proliferasi neuron sehingga jumlah neuron sehat mengimbangi neuron yang mengalami kerusakan. Skor ladder rung walking task yang meningkat pada tikus pasca stroke yang diberikan ekstrak etanol kacang tanah menggambarkan meningkatnya jumlah neuron yang sehat dibandingkan tanpa pemberian ekstrak etanol kacang tanah. Resveratrol juga mampu uptake glutamat yang terlah beredar pada celah sinaps sehingga mampu mencegah eksitotoksisitas yang selanjutnya menyebabkan kerusakan neuron..$^{20,21}$

\section{KESIMPULAN}

Pemberian ekstrak etanol kacang tanah berpengaruh terhadap penurunan kadar MDA, dan peningkatan fungsi motorik tikus model stroke iskemik. Dosis efektif ekstrak etanol kacang tanah dalam menurunkan kadar MDA, dan meningkatkan fungsi motorik tikus model stroke iskemik yaitu dosis $262 \mathrm{mg} / 250 \mathrm{gBB}$.

\section{KONFLIK KEPENTINGAN}

Penelitian dan publikasi artikel ini tidak didasarkan pada kepentingan pihak tertentu.

\section{UCAPAN TERIMAKASIH}

Terima kasih kepada pihak yang telah mendukung baik segi material dan moral hingga penelitian ini selesai.

\section{DAFTAR PUSTAKA}

1. Aminoff MJ, Greenberg DA, Simon RP. Clinical Neurology. $6^{\text {th }}$ ed. Foltin J, Fernando N, editors.USA: McGrawHill; 2005. p. 285-319.

2. Baehr M, Frotscher M. Duus' Topical Diagnosis in Neurology. $4^{\text {th }}$ ed. New York: Thieme; 2005. p. 418-77.

3. Bretón RR, César J, Rodríguez G. Excitotoxicity and Oxidative Stress in Acute Ischemic Stroke. 2012. p. 1-58.

4. World Health Organization. Global Atlas on Cardiovascular Disease Prevention And Control. Policies, Strategies and Interventions. WHO. Geneva. 2015.

5. World Health Organization. Global Burden of Stroke. WHO. 2015.

6. Badan Penelitian dan Pengembangan Kesehatan. Riset Kesehatan Dasar (RISKESDAS) 2013. Badan Litbangkes Kemenkes RI. Jakarta. 2013.

7. Flamm ES, Demopoulos HB, Seligman ML, Poser RG, Ransohoff J. Free Radicals in Cerebral Ischemia. AHA 1973; 9: 445-7.

8. Yuslianti ER. Pengantar Stres Oksidatif. Edisi 1. Rachman B, editor. 
Juliastuti, H : Ekstrak Etanol Kacang Tanah...

Cimahi: Fakultas Kedokteran Unjani; 2012.

9. Mergenthaler P, Dirnagl U, Meisel A. Pathophysiology of Stroke Lessons from Animal Models. Metab Brain Dis 2004; 19:151-67.

10. Phaniendra A, Jestadi DB, Periyasamy L. Free Radicals: Properties, Sources, Targets, and Their Implication in Various Diseases. Indian J Clin Biochem 2015; 30(1): 11-26.

11. Perhimpunan Dokter Spesialis Saraf Indonesia. Guideline stroke tahun 2011. PERDOSSI. Jakarta. 2011.

12. Wang X, Asahi M, Lo EH. Tissue type plasminogen activator: amplifies hemoglobin-induced neurotoxicity in rat neuronal cultures. Neuroscience Letter 1999; 274(2): 79-82.

13. Powers WJ, Derdeyn CP, Biller J, Coffey CS, Hoh BL, Jauch EC, et al. Guidelines for the Early Management of Patients With Acute Ischemic Stroke Regarding Endovascular Treatment. AHA 2015: 1-47.

14. Zhang F, Lu YF, Wu Q, Liu J, Shi JS. Resveratrol promotes neurotrophic factor release from astroglia. Experimental Biology and Medicine 2012; 273: 943-8.

15. Hussein MA. A convenient mechanism for the free radical scavenging activity of resveratrol. International Journal of Phytomedicine 2011; 3(4): 459-69.

16. Xia WC. Study on Extraction, Isolation and Antioxidant Activity of Resveratrol from Peanut Vine. China: Food Science and Engineering Jiangsu University. 2009.

17. Hu J, Han H, Cao P, Yu W, Yang C, Gao Y, et al. Resveratrol improves neuron protection and functional recovery through enhancement of autophagy after spinal cord injury in mice. Am J Transl Res 2017; 9(10): 4607-16.

18. Zavoreo I. Stroke and Neuroplasticity. Period Biol 2012; 114(3): 393-6.

19. Demarin V, Morovic S, Bene R. Neuroplasticity. Period Biol 2014; 116(2): 209-11.

20. Meredith Z, Alfred KA. Peanuts A source of medically important resveratrol. Natural Product Radiance 2003; 2(4): 182-9.

21. Candelario-jalil E, Oliveira ACP De, Gräf S, Bhatia HS, Hüll M, Muñoz E, et al. Resveratrol potently reduces prostaglandin $E 2$ production and free radical formation in lipopolysaccharide-activated primary rat microglia. Journal of Neuroinflammation 2007; 12: 1-12.

22. Gülçin İ. Antioxidant Properties of Resveratrol A Structure-Activity 
Juliastuti, H : Ekstrak Etanol Kacang Tanah...

Insight. Innov Food Sci Emerg Technol 2010; 11(1): 210-218.

23. Hau J, Meyer O, Svendsen O, et al. Handbook of Laboratory Animal Science. 2nd ed. Hau J, Hoosier V Jr, editors. USA: CRC; 2002.

24. Lukito AN, Indra MR. Ekstrak kulit dan biji anggur (Vitis vinifera) menurunkan jumlah sel neuron yang rusak, volume infark, dan memperbaiki fungsi motorik pada tikus wistar model stroke iskemik. Maj Kesehat FKUB 2016; 3.

25. Pusat Data dan Sistem Informasi Pertanian Kementerian Pertanian. Outlook Komoditas Pertanian
Tanaman Pangan Kacang Tanah. Kementerian Pertanian. Jakarta. 2015.

26. Desun EAR. Pengaruh Pemberian Ekstrak Kacang Tanah (Arachis hypogaea) terhadap Struktur Histologis Hepar Mencit yang Diinduksi Parasetamol. Surakarta: Fakultas Kedokteran Universitas Sebelas Maret. 2011.

27. Metz GA, Whishaw IQ. The Ladder Rung Walking Task: A Scoring System and its Practical Application. Journal of Visualized Experiments 2009; 28: $2-5$. 